\title{
Carcinoma of the Lacrimal Gland Pathologic Regional Lymph Nodes TNM
} Finding $v 7$

National Cancer Institute

\section{Source}

National Cancer Institute. Carcinoma of the Lacrimal Gland Pathologic Regional Lymph Nodes TNM Finding v7. NCI Thesaurus. Code C88798.

A pathologic finding about one or more characteristics of carcinoma of the lacrimal gland, following the rules of the TNM AJCC v7 classification system as they pertain to staging of regional lymph nodes. 